\title{
Effect of Polypropylene Fibers on the Shear Strength-Dilation Behavior of Compacted Lateritic Soils
}

\author{
Maitê Rocha Silveira ${ }^{1}$, Sabrina Andrade Rocha ${ }^{2}$, Natália de Souza Correia ${ }^{2}{ }^{\oplus}$, Roger Augusto Rodrigues ${ }^{1}$, \\ Heraldo Luiz Giacheti ${ }^{1}$ (i) and Paulo César Lodi ${ }^{1, *} \mathbb{B}$ \\ 1 Department of Civil and Environmental Engineering, São Paulo State University (UNESP), Av. Engenheiro \\ Luiz Edmundo Carrijo Coube 14-01, Bauru 17033-360, SP, Brazil; maite81@hotmail.com (M.R.S.); \\ roger.rodrigues@unesp.br (R.A.R.); h.giacheti@unesp.br (H.L.G.) \\ 2 Department of Civil Engineering, Federal University of Sao Carlos (UFSCar), Rodovia Washington Luiz, \\ São Carlos 17033-360, SP, Brazil; sabrina-andrade@outlook.com (S.A.R.); ncorreia@ufscar.br (N.d.S.C.) \\ * Correspondence: paulo.lodi@unesp.br; Tel.: +1-646-755-2239
}

\section{check for}

updates

Citation: Silveira, M.R.; Rocha, S.A.; Correia, N.d.S.; Rodrigues, R.A.; Giacheti, H.L.; Lodi, P.C. Effect of Polypropylene Fibers on the Shear Strength-Dilation Behavior of Compacted Lateritic Soils. Sustainability 2021, 13, 12603. https://doi.org/10.3390/ su132212603

Academic Editor: Castorina Silva Vieira

Received: 4 October 2021

Accepted: 5 November 2021

Published: 15 November 2021

Publisher's Note: MDPI stays neutral with regard to jurisdictional claims in published maps and institutional affiliations.

Copyright: (c) 2021 by the authors. Licensee MDPI, Basel, Switzerland. This article is an open access article distributed under the terms and conditions of the Creative Commons Attribution (CC BY) license (https:// creativecommons.org/licenses/by/ $4.0 /)$.

\begin{abstract}
The stress-dilatancy relationship for fiber-reinforced soils has been the focus of recent studies. This relationship can be used as a foundation for the development of constitutive models for fiber-reinforced soils. The present study aims to investigate the effect of recycled polypropylene fibers on the shear strength-dilation behavior of two lateritic soils using the stress-dilatancy relationship for direct shear tests. Results show that fibers improved the shear strength behavior of the composites, observed by increases in the friction angle. Fibers' orientation at the sheared interface could be observed. The volumetric change during shearing was altered by the presence of fibers in both soils. Overall, results indicate that the stress-dilatancy relationship is affected by inclusions in the soil mix. Results can be used to implement constitutive modeling for fiber-reinforced soils.
\end{abstract}

Keywords: polypropylene fibers; lateritic soil; shear strength; drained test; stress-dilatancy

\section{Introduction}

Aiming to reduce the production of waste generated worldwide in civil construction, the use of alternative materials has emerged as an urgent need in view of the current environmental challenges. Different alternatives appear in the geotechnical context for soil improvement, namely natural and synthetic fibers, rubber fibers, construction waste, and flakes [1-5]. The improvement of soil in many geotechnical applications (subgrades and subbases, the reinforcement of soft soils, the control of a soil's hydraulic conductivity, the improvement of erosion resistance, the prevention of piping, backfill in retaining structures, and shrinkage crack mitigation) has been done with the reinforcement of local soils with fibers [6-9]. The use of fibers to reinforce soils has been used as a sustainable reinforcement technique since it does not harm the environment and does not promote the removal of large volumes of soil for later compaction.

Extensive research has proven that reinforcing the soil with short, randomly distributed fibers (e.g., polypropylene and polyethylene terephthalate fibers) can improve the mechanical response of the soil, observed by an interception in the potential failure zone, fiber tensile strength mobilization, and an improvement in the soil ductility [10-13], as well as provide isotropic behavior and limit the development of weak planes [14]. Anagnostopoulos et al. [15] state that the bond's interfacial strength due to mechanical interlocking along the friction at the interface seems to be the dominant mechanism that controls the micromechanical benefits of the reinforcement of soil with fibers.

Recent studies available in the literature regarding clayey soils mixed with short, randomly distributed polymeric fibers provide evidence of the significant impact of the inclusion of fibers on the soil shear strength [13,16-20]. Most of these studies assessed the effectiveness of fiber reinforcement using uniaxial, direct shear, and triaxial 
tests $[10,13,21-29]$. However, comparing the numerous published studies on sand-fiber mixtures, studies on clayey soils reinforced with fibers are limited despite the equal potential for geotechnical applications.

For Anagnostopoulos et al. [30], the existing studies on fiber-reinforced clays have not yet established the fundamental mechanisms or the conditions that may affect the behavior of these fiber mixtures. According to Freilich et al. [31], there is a need for advancing studies in this field of knowledge due to the greater complexity related to the fiber interaction mechanism in cohesive soils. In addition, most studies do not present a deeper analysis regarding the stress-dilatancy behavior of soils reinforced with fibers. As stated by $\mathrm{Li}$ and Zornberg [32], the main findings in fiber reinforcement research regard increases in the soil shear strength and the post peak strength and changes in the soil ductility.

The stress-dilatancy relationship for fiber-reinforced soils has been the focus of some recent studies. The concept of fiber space was introduced by Wood et al. [33] to describe significant changes in the dilatancy of fiber-reinforced sands [34]. For Kong [35], when a polypropylene fiber-soil assembly dilates in response to applied shear deformations, the work done by the driving stress will be dissipated by not only particle sliding but also the fiber deformation. Eldesouky et al. [14] conducted direct shear tests on polypropylenefiber-reinforced sands and proved that as the specimen approaches failure, fiber-reinforced specimens have higher dilation angles than unreinforced ones, explained by an increase in the shear zone that leads to higher dilation angles. Kong et al. [34] conducted several triaxial compression tests to investigate the effect of uniformly distributed fiber reinforcements on the stress-dilatancy relationship of Nanjing sand. The authors propose a new stress-dilatancy relationship for fiber-reinforced sand based on Rowe's stress-dilatancy relationship [36] for granular materials and suggest that the results could be employed as a foundation for the development of a constitutive model for polypropylene-fiber-reinforced soils. According to Kong et al. [34], the extension of fibers due to rearrangement and microstructure disturbances during shearing provides an important contribution to the increase in strength; however, studies are not conclusive on the observed stress dilatancy of fiber-reinforced soils.

A recent study by Dołżyk-Szypcio [37] using the stress-dilatancy relationship for the direct shear tests developed by Szypcio [38] emphasizes that the stress-dilatancy relationship is a function of moisture, the degree of compaction, and normal stresses and can be affected by inclusions in the soil mix. Szypcio [38] suggests further experimental investigation, especially for cohesive soils on different stress-strain paths. Regarding the stress-dilatancy relationship of fine and cohesive soils, Yousefpour et al. [39] evaluated the shear strength-dilation characteristics of silty and clayey sands and demonstrate that the shear strength, dilation angle, and maximum friction angle decreased with an increase in the clay content and increased with an increase in the silt content. According to Yousefpour et al. [39], few studies are concerned with the relationship between the strength parameters and the dilation of silty and clayey sands. The authors suggest that the direct shear apparatus is a useful tool for the investigation of the shear strength and dilation characteristics of fine soils.

As exposed by the literature, there is a need for investigations regarding the shear stress-dilatancy behavior of fine soils and the influence of the inclusion of fibers on the strength and dilatancy behavior of fine soil mixtures. Studies related to fine-grained and clayey lateritic soils reinforced with polymeric fibers are scarce in the literature $[4,5]$. The present study combined an investigation of the shear strength-dilation behavior of two lateritic fine soils reinforced with short, randomly distributed polypropylene fibers. Analyses were conducted using the stress-dilatancy model for the drained direct shear tests developed by Szypcio [38].

\section{Materials and Methods}

Two lateritic soils (clayey sand and clay), taken from the state of Sao Paulo in Brazil, were chosen for this research since they represent typical soils that cover a large area in 
Brazil. The lateritic soils, due to their formation process, underwent leaching processes. The clay fractions are essentially composed of clay minerals from the Kaolinite group and hydroxides and hydrated oxides of iron and/or aluminum [40,41]. The clayey soil was collected from the city of Santa Gertrudes, Sao Paulo and classified as $\mathrm{CH}$ soil according to the Unified Soil Classification System [42] although a significant percentage of sand was present. The clayey sand, classified as SC soil [42], was collected from the city of Bauru, Sao Paulo. According to X-ray diffraction analysis [43], the predominant clay minerals in both lateritic soils were Kaolinite, Illite, Gibbsite, and Hematite. In these soils, the formation of aggregates of finer soil particles is common due to the action of iron and aluminum oxides and hydroxides, a characteristic that explains the peculiar behavior of lateritic soils.

The soil samples were characterized by particle size analysis [44], specific gravity [45], Proctor tests [46], and consistency limits [47]. The physical properties of the soils are presented in Table 1. The particle distribution of the soils is shown in Figure 1.

Table 1. Characteristics of the natural lateritic soils used in this study.

\begin{tabular}{cccc}
\hline Properties & Values & Specification \\
\hline & CH & SC & \\
\hline Clay fraction (\%) & 50 & 14 & \\
Silt fraction (\%) & 14 & 5.8 & ASTM D7928 [44] \\
Sand fraction (\%) & 36 & 80.2 & \\
Specific gravity of solids & 2.90 & 2.65 & ASTM D854 [45] \\
Liquid limit (\%) & 51 & 16 & \\
Plasticity limit (\%) & 29 & 2 & ASTM D4318 [47] \\
Plasticity Index (\%) & 22 & 14 & \\
Maximum dry unit weight $\left(\mathrm{kN} / \mathrm{m}^{3}\right)$ & 16.7 & 19.50 & ASTM D698 [46] \\
Optimum water content $(\%)$ & 24.0 & 10.6 & \\
\hline
\end{tabular}

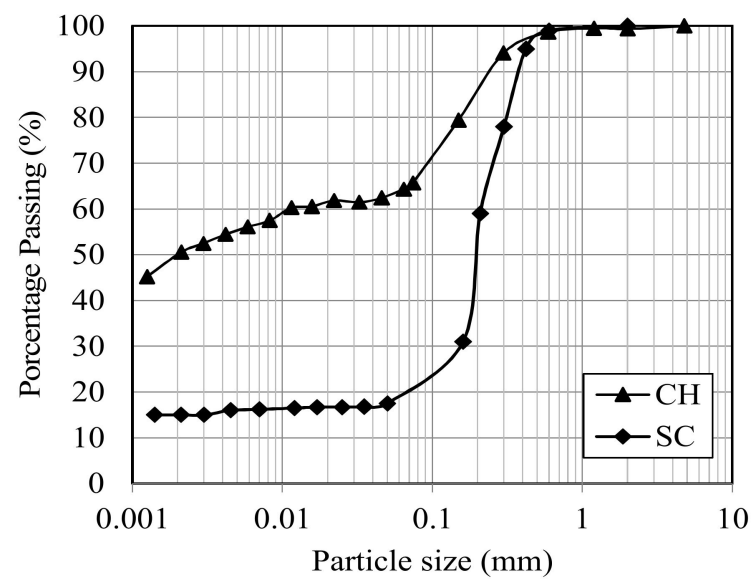

Figure 1. Particle size distribution curves of $\mathrm{SC}$ and $\mathrm{CH}$ soils.

The fibers used in this research were characterized as short, discrete recycled polypropylene (PP) fibers of light weight and high flexibility that were hydrophobic and inert. The PP fibers had an average diameter of 18 micrometers, a specific mass of $0.9 \mathrm{~g} / \mathrm{cm}^{3}$, an average length of $18 \mathrm{~mm}$, zero water absorption, and a breaking tensile strength of $610 \mathrm{MPa}$.

Figure 2 presents the PP fibers used in this study and the samples' preparation. PP fibers were randomly distributed into the soil mass at a fiber content of $0.1 \%$ and $0.25 \%$ by soil dry weight. These fiber contents are representative of the contents used in soil mixtures in other studies $[16,19,31,48-51]$. The soil was homogenized using the optimum water content of the natural soil, which was obtained from the compaction test in normal Proctor energy by calculating the amount of water in relation to the total weight of the dry raw material (soil + fiber). 
(a)

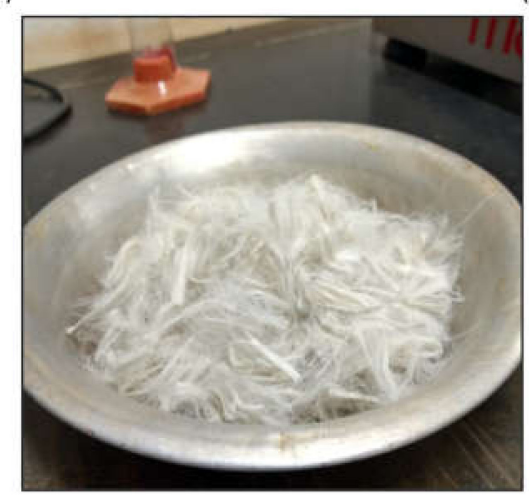

(b)

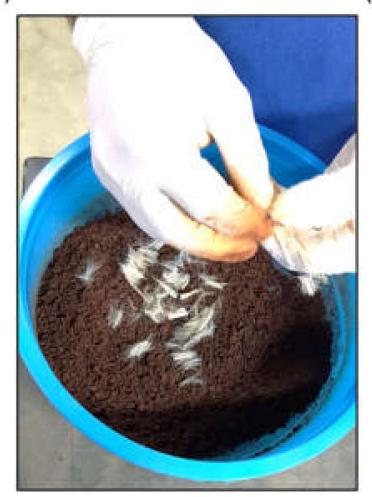

(c)

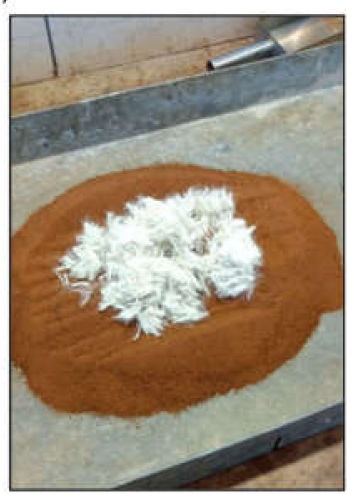

Figure 2. Sample preparation: (a) fibers; (b) mixture with $\mathrm{CH}$ soil; (b) mixture with SC soil.

Fibers were randomly distributed in the soil matrix and a mechanical mixer was used to reach a homogenous fiber distribution in the soil and to avoid any potential weakness plane. Fibers' mixture in the CH soil was done with humidified soil due to the difficulty of moistening and homogenizing the dry soil with fibers. In the field, special attention to the mixture's production is necessary. Some remarks on the limitations of quality control procedures can be found in Farloca et al. [52].

In order to obtain the target compaction parameters for each soil mixture, standard Proctor compaction tests [46] were also conducted on the soils with fiber reinforcements. Prior to compaction, prepared mixtures were preserved in air-proof bags for a minimum of 24 hours for moisture homogenization. The optimum compaction conditions were used as the target compaction parameters for the direct shear tests.

This study involved drained direct shear tests that were conducted according to ASTM D3080 [53] on the compacted soil specimens. The specimens (with and without fibers) were compacted using the optimum water content and a $95 \%$ compaction degree. The test was conducted on a shear box with dimensions of $100 \times 100 \times 25 \mathrm{~mm}$, where the lower part of the shear box is restrained, while the upper part is controlled by a motor to apply a horizontal shear load in displacement-controlled mode. Since the tests were carried out in different months, the research with clayey soil specimens was initially performed under vertical stresses of 100,200, and $300 \mathrm{kPa}$ prior to shearing. Then, the research continued, and the sandy soil specimens were consolidated under vertical stresses of 100, 200, and $400 \mathrm{kPa}$. Tests were conducted at a loading rate of $0.15 \mathrm{~mm} / \mathrm{min}$ in all tests. We did not use duplicated soil samples to study the effect of structure on the stress-strain behavior of reconstituted soil samples. Only one test per normal stress level was conducted. During the tests, loads and displacements in the axial and horizontal directions were recorded automatically by a computer-controlled data collection system. Shear stress was recorded as a function of horizontal displacement up to a total displacement of $15 \mathrm{~mm}$ in order to observe the post-failure behavior.

\section{Results and Discussion}

\subsection{Influence of PP Fibers on Compaction Properties}

Figure 3 shows the compaction curves of both soil mixtures with $0.1 \%$ and $0.25 \%$ fiber content, compared to the respective natural soils. The behavior of the maximum dry unit weight did not change with the inclusion of fibers in the clayey soil, while the optimum gravimetric water content increased by $0.5 \%$ for the $0.25 \%$ fiber content. The behavior of the maximum dry unit weight did slightly reduce with the inclusion of fibers in the sandy soil, while the optimum gravimetric water content did not change. The results of other studies show similar compaction curves for soils with and without fiber reinforcement [54-56], where no significant alterations were evidenced. 
(a)

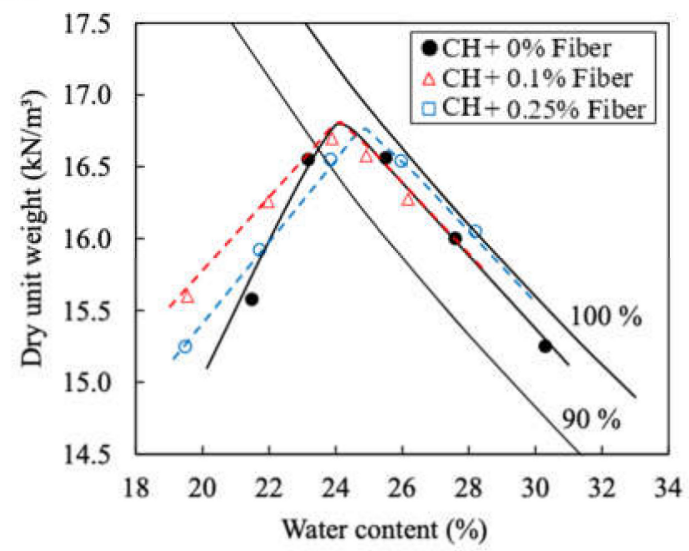

(b)

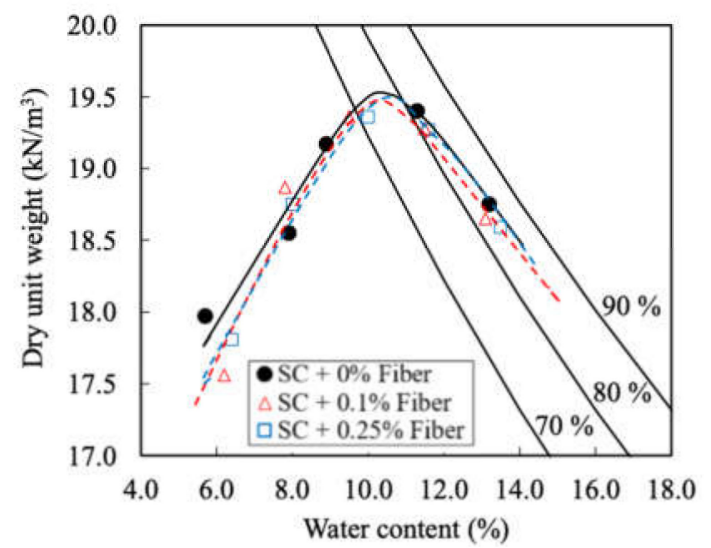

Figure 3. Standard Proctor compaction curves for soil with fiber contents of $0.0 \%, 0.1 \%$, and $0.25 \%$ : (a) $\mathrm{CH}$; (b) SC.

\subsection{Influence of PP Fibers on Drained Shear Strength}

The results of direct shear tests considering each combination of lateritic soil and PP fibers are presented in Figures 4 and 5, showing the variations in shear stress and volumetric change with shear displacements. In Figure 4, the inclusion of fibers in the $\mathrm{CH}$ soil improved the shear strength behavior of the composites, beyond which it remained constant for $0.1 \%$ fiber content. The contribution of the fibers to the increase in soil strength was superior for the highest fiber content $(0.25 \%)$ and, after the mixtures underwent plastic deformation, the resistance of fibers was mobilized, and hardening was observed. This behavior is in accordance with the results presented in the research of Anagnostopoulos et al. [15] that studied the shear strength behavior of polypropylene-fiber-reinforced cohesive soils. The continuous increase in shear stress, mainly for the highest normal stresses, was justified in Khatri et al. [57] by the mobilization of the tensile strength of the fibers, which increases the deformation imposed on the material at failure. Regarding the volume change versus shear displacement plots for the $\mathrm{CH}$ soil (Figure 4), the results evidence, at all stress levels, a lower degree of contraction of fiber-reinforced specimens than that of unreinforced specimens, directly related to the fiber content. This behavior was also found in the research of Anagnostopoulos et al. [15]. Specimens exhibited a trend of dilation occurring under drained shearing for lower stresses and contraction occurring under higher stresses. The volumetric change was altered by the presence of fibers, mainly at higher stress levels, and indicates that the presence of fibers considerably limited the tendency for contraction. Similar results were obtained by Sadek et al. [58] and Ibraim et al. [59]. According to Anagnostopoulos et al. [15], these results suggest that the volumetric response, from contractive to dilative, could be a consequence of an apparent densification of the composite matrix resulting from the interaction mechanism between the fiber net and the soil particles.

Regarding SC soil (Figure 5), the inclusion of polymeric fibers increased the shear strength of the soil for higher normal stresses and the higher fiber content. The hardening behavior observed for $\mathrm{CH}$ soil was not evidenced in SC specimens. Regarding the volumetric change results, a trend of a decrease (contraction) in the volume variation was observed at all stress levels, although the addition of fibers did not produce a trend of a volume increase as in the $\mathrm{CH}$ soil. This behavior was also found in the results of Silveira et al. [5], who used polyethylene strips in SC lateritic soil. Maher and Gray [60] and Consoli et al. [61] state that the effect of the inclusion of fibers on the dilation and volume change is more pronounced at higher loads and strain levels. Regarding the initial tangent stiffness of the shear stress-displacement curves, the inclusion of polymeric fibers in both $\mathrm{CH}$ and SC soils practically did not affect this property. 
(a)
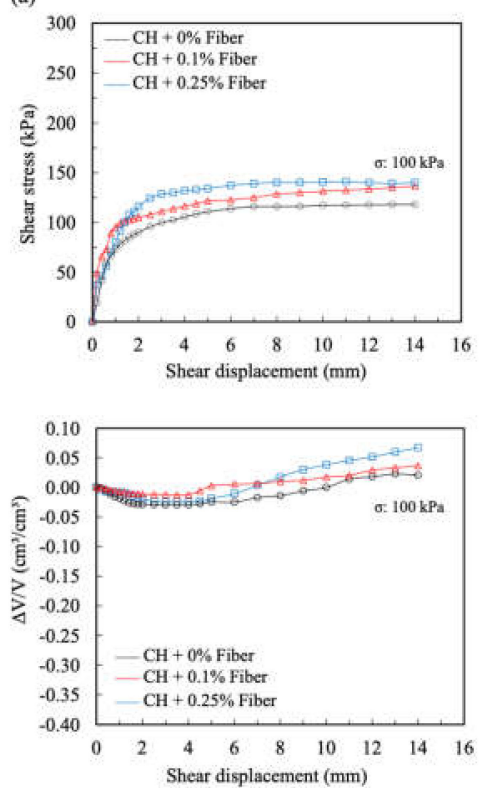

(b)
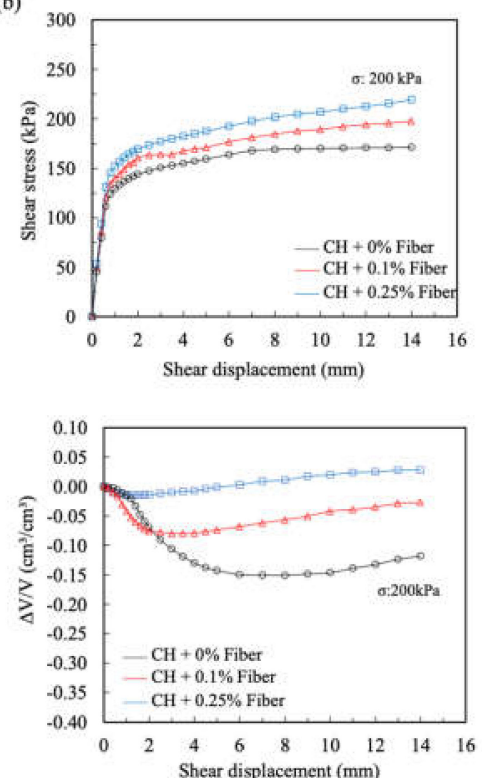

(c)
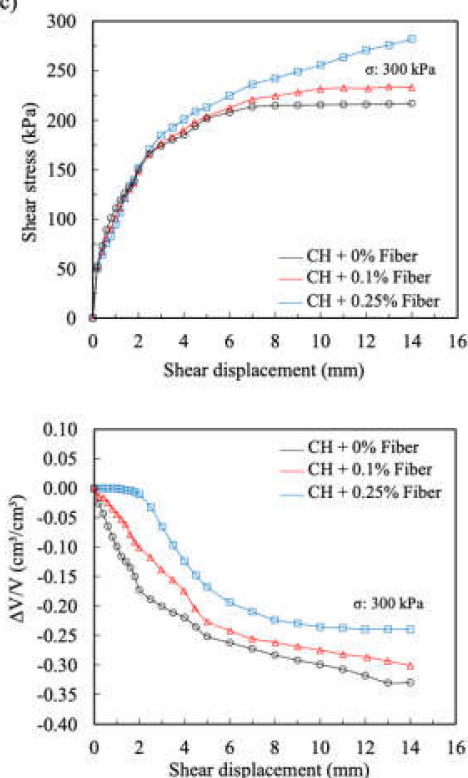

Figure 4. Shear stress and volume change vs. displacement for $\mathrm{CH}$ soil with fiber contents of $0.0 \%, 0.1 \%$, and $0.25 \%$ : (a) $100 \mathrm{kPa}$; (b) $200 \mathrm{kPa}$; and (c) $300 \mathrm{kPa}$.

(a)
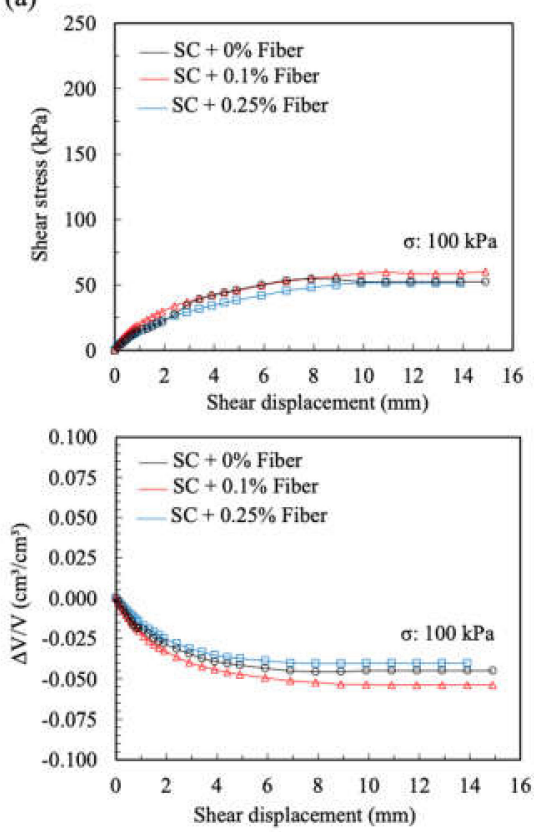

(b)
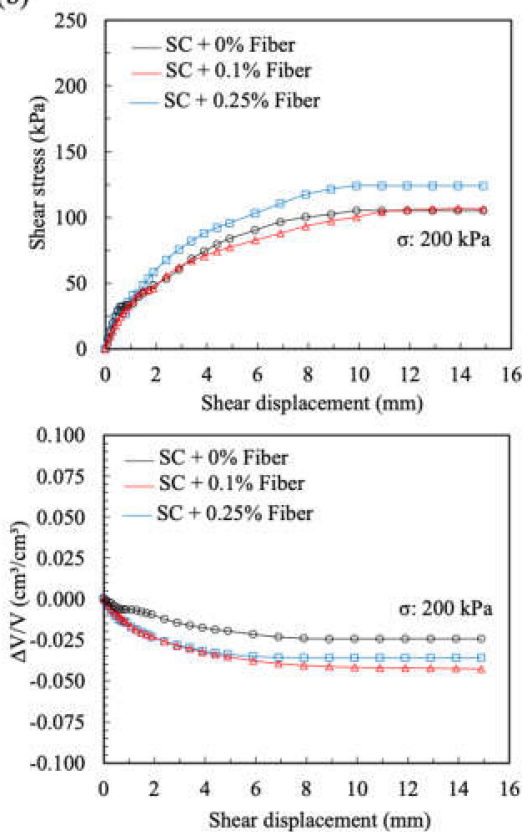

(c)
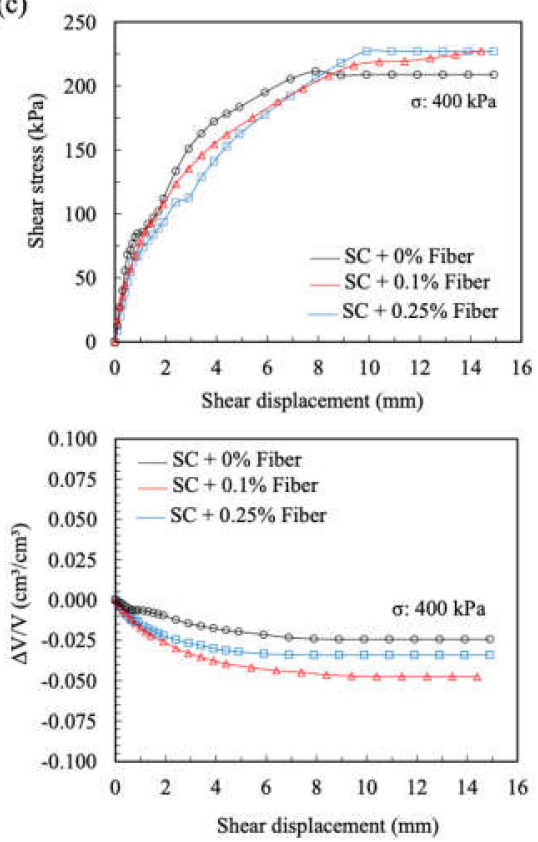

Figure 5. Shear stress and volume change vs. displacement for SC soil with fiber contents of $0.0 \%, 0.1 \%$, and $0.25 \%$ : (a) $100 \mathrm{kPa}$; (b) $200 \mathrm{kPa}$; (c) $400 \mathrm{kPa}$.

Figure 6 presents the soil-fiber specimens after shear tests, showing the fibers' orientation at the sheared interface in the $\mathrm{CH}$ soil. No deformation or breakage of fibers was observed. Kumar and Singh [62] state that an improvement in the ductility of soil through the stretching of the fibers causes an increase in the soil's cohesion. According to Darvishi and Erken [51], because of the extensible nature of the fibers, they are stretched in the soil matrix during the shearing process, increasing the tension strength of fiber-reinforced soils. Kong et al. [34] state that the extension of fibers due to rearrangement and microstructure disturbances during shearing provides an important contribution to the increase in strength. 
For Anagnostopoulos et al. [15], this is a confirmation that fibers withstand tension within the soil matrix without significantly deforming.
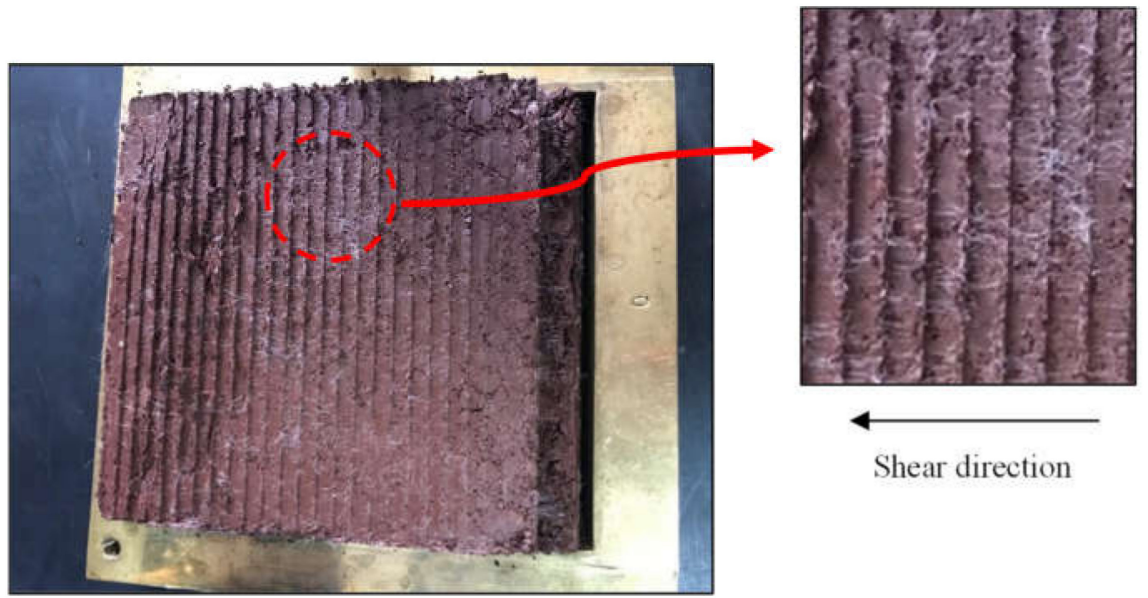

Figure 6. Fibers' orientation during shearing in lateritic $\mathrm{CH}$ soil.

The shear strength envelopes for mixtures with $0 \%, 0.1 \%$, and $0.25 \%$ fiber contents are shown in Figure 7. The failure criterion adopted was the value of peak shear strength. The results shown in Figure 7 evidence the friction behavior of SC soil and the high cohesion $(69.2 \mathrm{kPa})$ and friction angle $\left(26.1^{\circ}\right)$ of the lateritic clayey soil. Indeed, compacted tropical soils exhibit good shear strength behavior when unsaturated [63]. After the inclusion of fibers, an increase in the cohesion and the friction angle was observed with increasing fiber content in the $\mathrm{CH}$ soil. The results of Tang et al. [6] on clayey soil reinforced with 12-mm-long PP fibers showed that the values of cohesion and friction angles also increased with increasing fiber content.

(a)

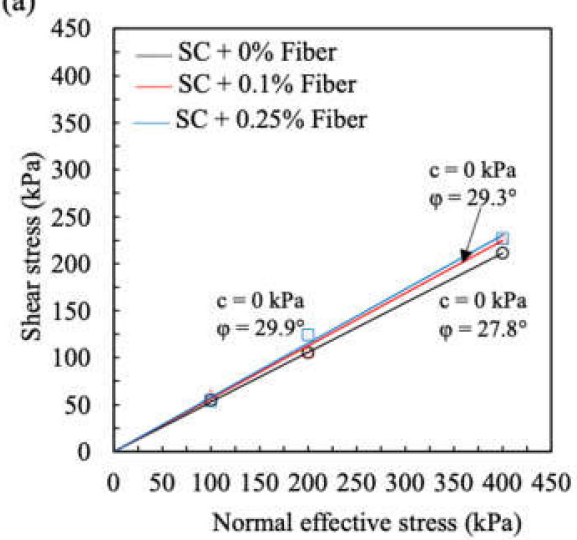

(b)

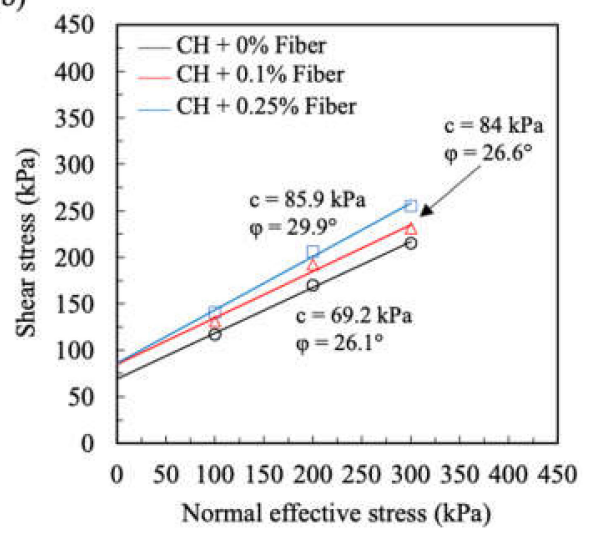

Figure 7. Shear strength envelopes of natural soil and soil with $0.1 \%$ and $0.25 \%$ fiber content: (a) $\mathrm{CH}$; and (b) SC.

The effect of the addition of fibers on the shear strength parameters of SC soil was evidenced by an increase in the friction angle (Figure $7 \mathrm{~b}$ ), although it was not influenced by the increase in fiber content. The improvement in the friction angle is most probably associated with the mobilization of friction between the soil particles and the fibers $[64,65]$ and due to the relative size of the fibers and soil grains [15].

In order to evaluate the variation in the shear strength response with fiber contents and normal stress levels, the following strength ratio parameter proposed by Darvishi and Erken [51] was used:

$$
R=\frac{\tau}{\tau_{u n}}
$$


where $\tau$ and $\tau_{u n}$ are the stresses of fiber-reinforced and unreinforced soil at the peak shear value, respectively.

Figure 8 presents results on the strength ratio in the evaluated lateritic soils with different PP fiber contents and with normal stress levels. For the $\mathrm{CH}$ soil (Figure 8a,c), the strength ratios were observed to be as high as 1.2 with increasing PP fiber content and the $\mathrm{CH}$ soil showed decreased strength ratios under higher normal stresses. The SC soil (Figure $8 \mathrm{~b}, \mathrm{~d}$ ) presented alterations in the strength ratio, such as a drop with higher normal stresses, which was also observed in the sand-fiber mixture evaluated by Darvishi and Erken [51]. In this case, reinforcement with fibers was more effective for specimens under low normal stress and $0.25 \%$ fiber content.

(a)

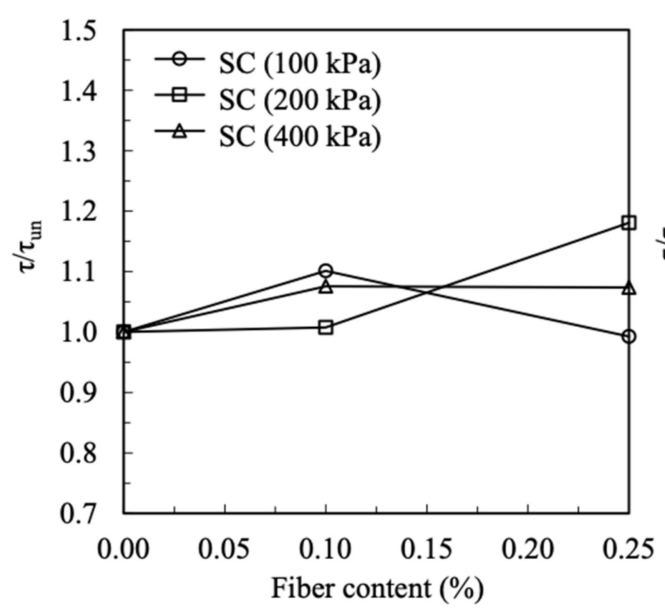

(b)
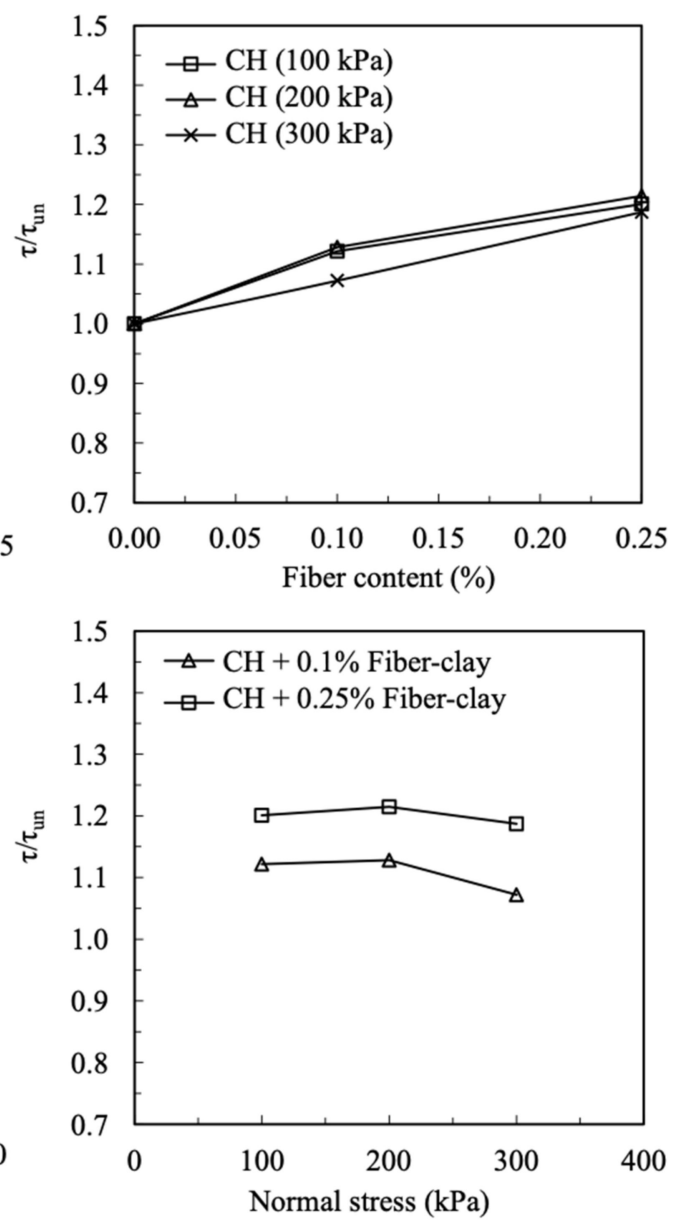

Figure 8. Variation in the shear strength ratio with fiber content and normal stresses: (a) SC; (b) $\mathrm{CH}$.

\subsection{Influence of PP Fibers on the Stress-Dilatancy of Soil Mixtures}

Figures 9 and 10 show a plot of the stress ratio $\left(\tau / \sigma_{n}\right)$ against the dilatancy results of the natural soil and the fiber-reinforced mixtures for the different normal stress levels, respectively, for $\mathrm{SC}$ soil and $\mathrm{CH}$ soil. As shown in Figure 9, at all test stages, the specimens experienced high contraction rates (negative dilation angles) and the influence of the fibers is evidenced by the stress-dilatancy behavior of the SC soil mixtures. The results on the stress-dilatancy behavior of reinforced soil mixtures are in accordance with the results of Eldesouky et al. [14] in which the contraction rates increased with an increase in the fiber content. Figure 10 shows that adding $0.25 \%$ fiber content to the $\mathrm{CH}$ soil significantly alters the stress-dilatancy behavior of the soil mixture as compared with the addition of $0.1 \%$ fiber content. In this case, the clayey soil was more susceptible to alterations in the stress-dilatancy behavior of the soil than sandy soil. 

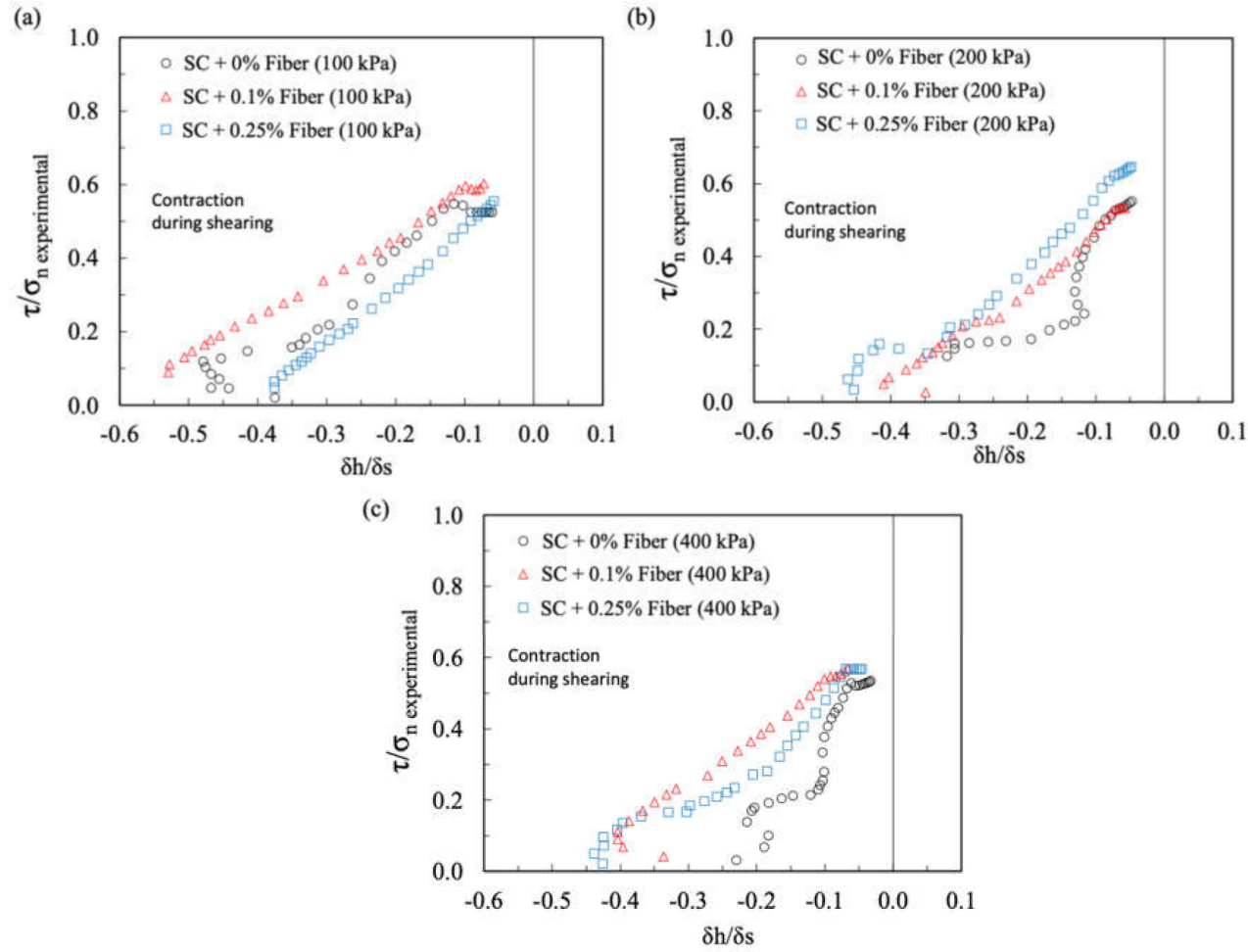

Figure 9. Influence of the inclusion of fibers on the stress-dilatancy behavior under direct shear conditions for SC soil: (a) $100 \mathrm{kPa}$; (b) $200 \mathrm{kPa}$; (c) $400 \mathrm{kPa}$.

(a)

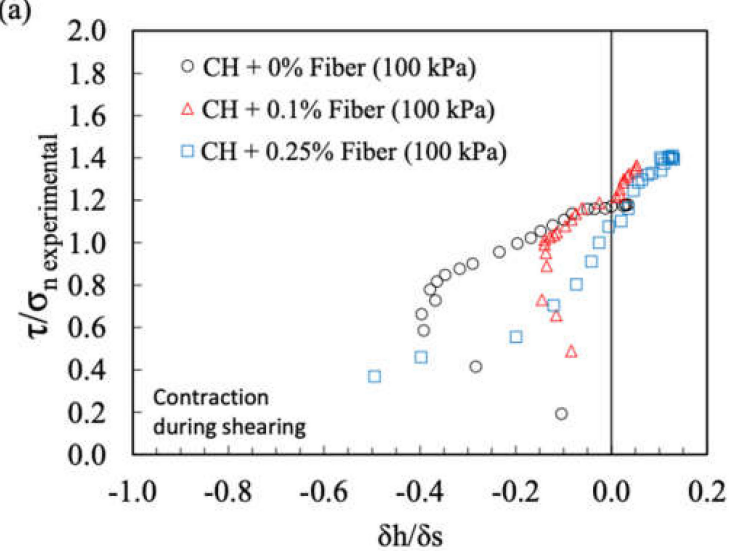

(b)

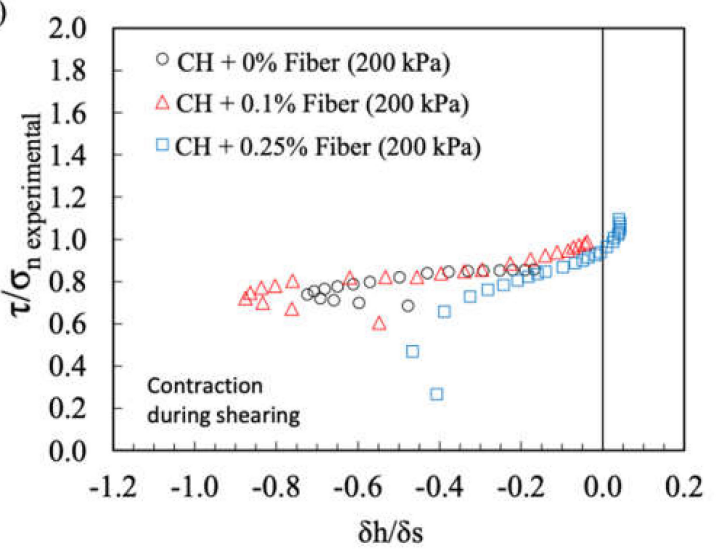

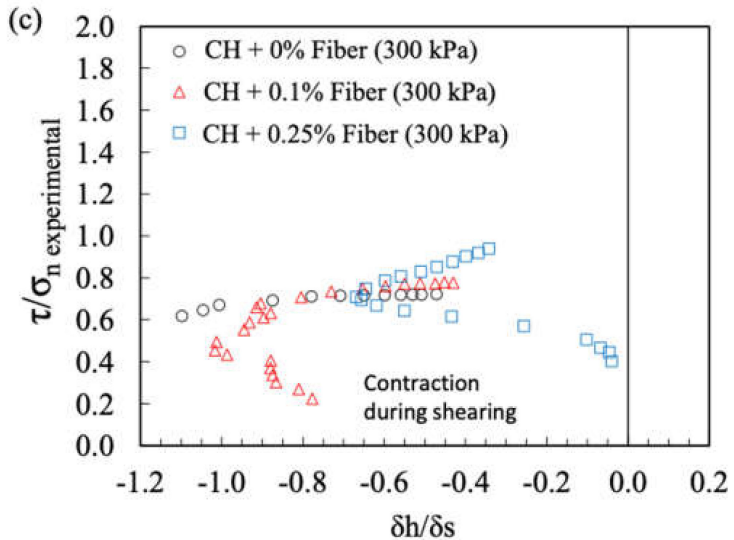

Figure 10. Influence of the inclusion of fibers on the stress-dilatancy behavior under direct shear conditions for $\mathrm{CH}$ soil: (a) $100 \mathrm{kPa}$; (b) $200 \mathrm{kPa}$; (c) $300 \mathrm{kPa}$. 
Szypcio [38] developed a complex equation that represents the stress-dilatancy relationship for the simple shear condition, obtained from the frictional state theory. According to Szypcio [38], the stress-dilatancy Equation (4) for the simple shear test can be used for direct and ring shear tests, as follows:

$$
\frac{\tau}{\sigma}=\frac{\sqrt{3} \eta \cos \Phi^{\circ} \cos \theta}{3+\eta\left(\sin \theta-\sqrt{3} \sin \Phi^{\circ} \cos \theta\right)}
$$

where:

$$
\begin{gathered}
\eta=Q-A D \\
Q=M^{\circ}-\alpha A^{\circ} \\
M^{\circ}=\frac{3 \sin \Phi^{\circ}}{\left.\sqrt{3} \cos \theta-\sin \Phi^{\circ} \sin \theta\right)}
\end{gathered}
$$

for the drained condition,

$$
\begin{gathered}
A^{\circ}=\frac{1}{\cos \left(\theta-\theta_{\varepsilon}\right)}\left\{1-\frac{2}{3} M^{\circ} \sin \left(\theta+\frac{2}{3} \pi\right)\right\} \\
A=\beta A^{\circ} \\
\theta_{\varepsilon}=\arctan \left\{\frac{1}{\sqrt{3}} \frac{\frac{\delta h}{\delta s}}{\sqrt{1+\left(\frac{\delta h}{\delta s}\right)^{2}}}\right\} \\
D=-\sqrt{3} \frac{\frac{\delta h}{\delta s}}{\sqrt{1+\frac{4}{3}\left(\frac{\delta h}{\delta s}\right)^{2}}}
\end{gathered}
$$

where $\Phi^{\circ}$ is the critical frictional state angle, $\alpha$ and $\beta$ are frictional state theory parameters, $\mathrm{h}$ is the growth in the sample's height during shear, and $\mathrm{s}$ is the displacement of the shear box.

Based on the experimental data on non-cohesive soils, the stress-dilatancy relationship calculated using the frictional state theory with $\Phi^{\circ}=\Phi_{\mathrm{cv}}, \theta=15^{\circ}, \alpha=0$, and $\beta=1.4$ is acceptable [38]. Figure 11 shows an example of the stress ratio-dilatancy relationship for the mentioned parameters.

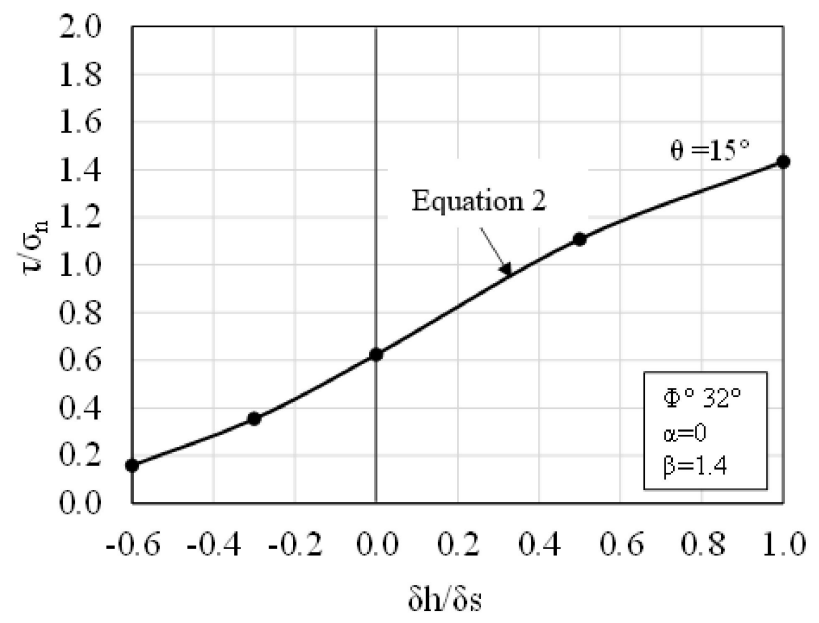

Figure 11. Stress-dilatancy relationship developed by Szypcio [38] (modified).

According to the proposed model, parameters $\alpha$ and $\beta$ represent the mode of deformation in the shear band. Parameter $\alpha$ translates the reference curve obtained for $\alpha=0$ 
upward for $\alpha<0$ and downward for $\alpha>0$. Parameter $\beta$ significantly influences the stress ratio-dilatancy relationship for dilation and contraction during shearing. For almost all tests, in the initial phase of shearing, the relationship between $\tau / \sigma$ n and $\delta h / \delta s$ is not linear, while in the pre-peak and post-peak phases of shearing, a linear relationship $\tau / \sigma n-\delta h / \delta s$ is observed, and parameters $\alpha$ and $\beta$ can be calculated by use of an approximation technique [37,38]. In the study of Dołżyk and Szypcio [37], the pre-peak and post-peak phases of shearing were obtained with parameter intervals of $0.1<\alpha<1.1$ and $2.1<\beta<6.0$ (large direct shear box) and $\alpha=0$ and $\beta=1.4$ (small direct shear box), showing a higher degree of non-homogeneous deformation in the shear band in the large box apparatus.

The results on stress-dilatancy relationships for the SC soil and the fiber-reinforced mixtures are shown in Figure 12. The best fit obtained using Equation (2) well approximates the experimental relationship at failure (pre-peak experimental data) for $\Phi^{\circ}=32^{\circ}$, $-0.15<\alpha<-0.1$, and $2.0<\beta<2.4$. According to Figure 12, the increase in parameter $\beta$ after the inclusion of fibers in the SC soil demonstrates the influence on the stress ratio-dilatancy relationship during shear, which was superior for the higher fiber content. As also observed by Dołżyk and Szypcio [37], this indicates that the stress-dilatancy relationship is affected by inclusions in the soil mix.
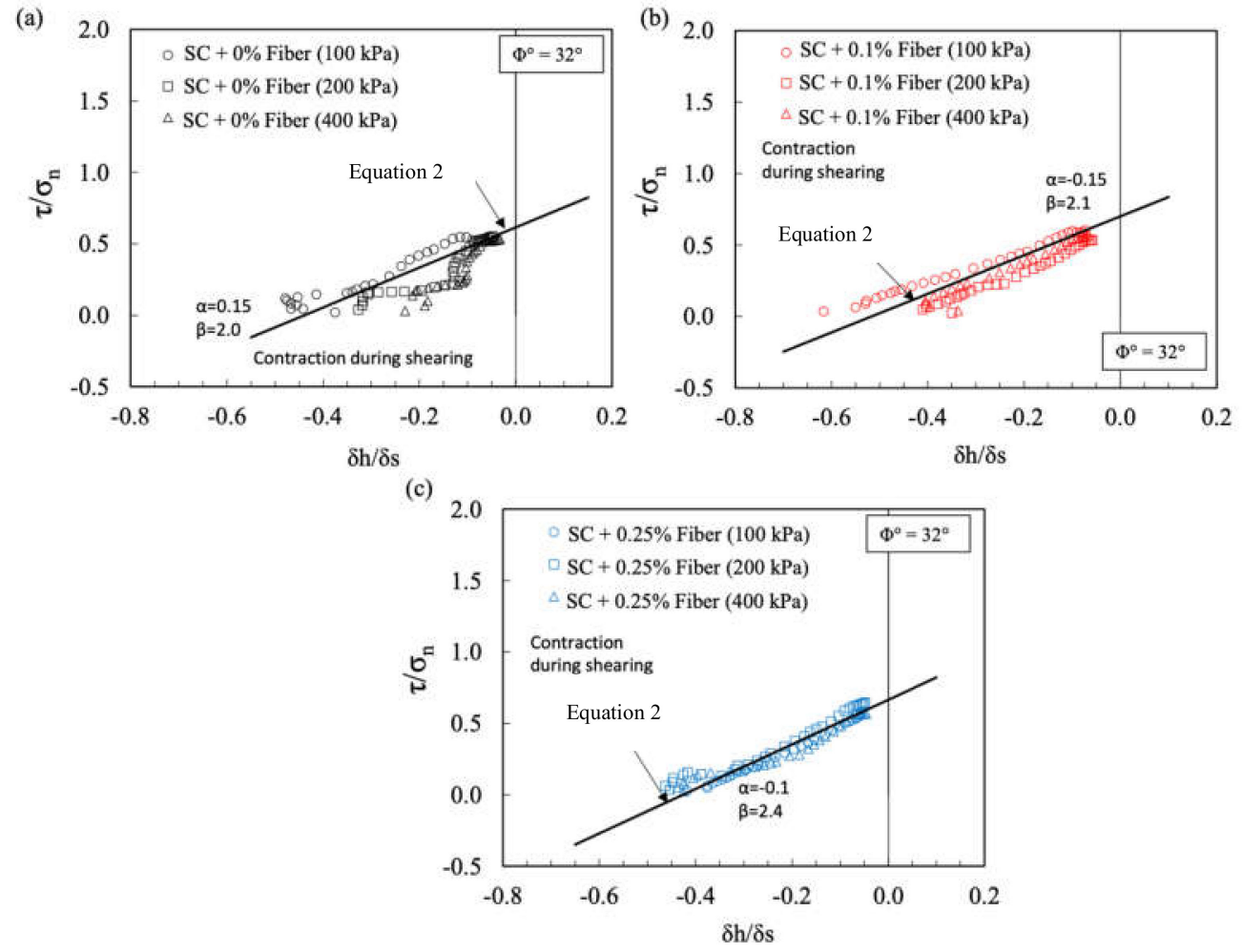

Figure 12. Influence of the inclusion of fibers on the stress-dilatancy relationship under direct shear conditions for SC soil: (a) $100 \mathrm{kPa}$; (b) $200 \mathrm{kPa}$; (c) $400 \mathrm{kPa}$.

An approach for cohesive soils was used to understand the stress-dilation behavior of the $\mathrm{CH}$ soil. According to BS8002 [66], for fine soils, the critical frictional state angle can be estimated based on Atterberg limits as follows:

$$
\Phi^{\circ}=42-12.5 \log (P I) \text { for } 5 \%<P I<100 \%
$$

where $P I$ is the soil plasticity index.

In the natural clayey soil (Figure 13), the best fit obtained using Equation (2) well approximates the experimental relationship at failure (pre-peak experimental data) for $\Phi^{\circ}=25.2^{\circ},-0.9<\alpha<-0.8$, and $1.0<\beta<1.1$. In general, the stress-dilatancy behavior of the clayey samples was not affected by the inclusion of fibers, which was observed by the parameters with the same fit. However, the pre-peak and post-peak phases of shearing 
showed different behaviors when comparing the natural and fiber-reinforced samples. These results can be used to develop constitutive models for fiber-reinforced soils.

(a)

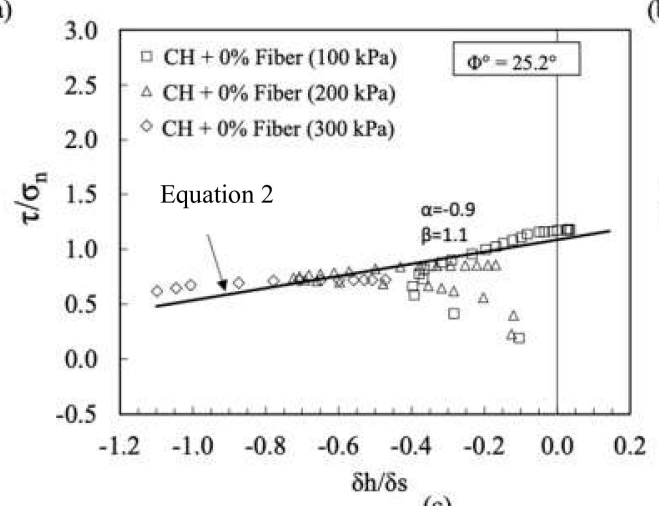

(b)

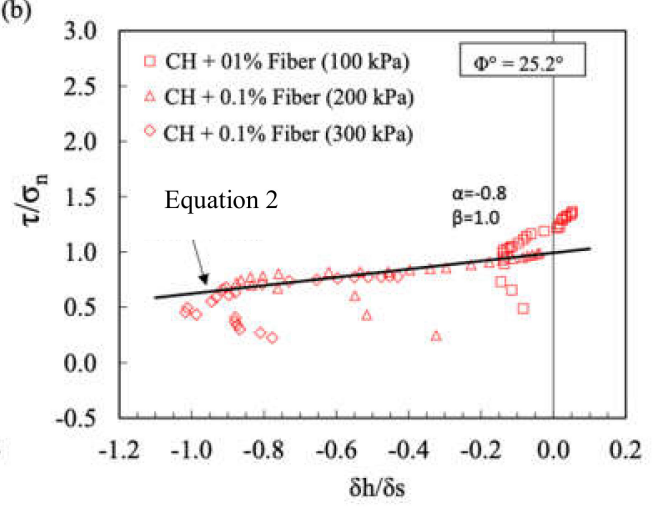

(c)

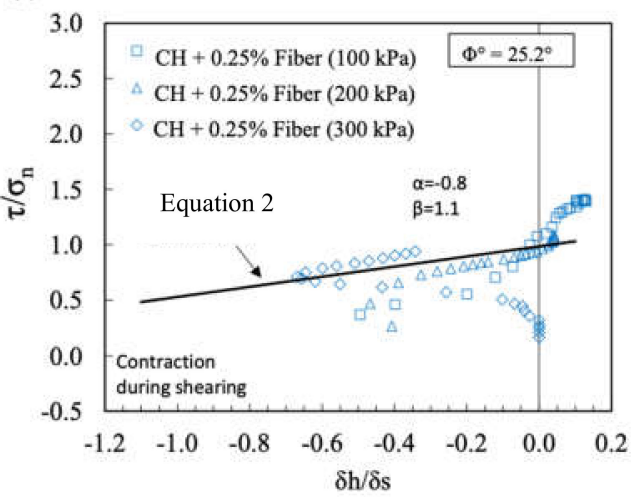

Figure 13. Influence of the inclusion of fibers on the stress-dilatancy relationship under direct shear conditions of $\mathrm{CH}$ soil: (a) $100 \mathrm{kPa}$; (b) $200 \mathrm{kPa}$; (c) $300 \mathrm{kPa}$.

\section{Conclusions}

This study investigated the effect of recycled polypropylene fibers on the shear strength-dilation behavior of two lateritic soils using the stress-dilatancy relationship for direct shear tests. The following conclusions can be drawn:

1. The inclusion of PP fibers improved the shear strength behavior of the composites in both soils, while the soils' initial stiffness was practically not affected;

2. The contribution of the fibers to the increase in the soil strength was superior in the clayey soil and for the highest content $(0.25 \%)$, observed by a substantial increase in the friction angle. The resistance of fibers was mobilized, and soil hardening was observed. Fibers' orientation at the sheared interface could be observed;

3. The volumetric change in the clayey soil was altered by the presence of fibers under drained shear mainly at higher stress levels. The results indicate that the presence of fibers considerably limited the tendency for contraction. A trend of a decrease in the volume variation was observed for higher normal stresses in the sandy soil; and

4. The Szypcio [38] model demonstrated the influence on the stress ratio-dilatancy relationship during shear, which was superior for the higher fiber content in the sandy soil. In the clayey soil, the pre-peak and post-peak phases of shearing showed different behaviors when comparing natural and fiber-reinforced samples. Overall, the results indicate that the stress-dilatancy relationship is affected by inclusions in the soil mix.

Author Contributions: Conceptualization, M.R.S., S.A.R., P.C.L. and N.d.S.C.; methodology, M.R.S., S.A.R., P.C.L., N.d.S.C., R.A.R. and H.L.G.; formal analysis, M.R.S., S.A.R., P.C.L., N.d.S.C., R.A.R. and H.L.G.; investigation, M.R.S., S.A.R., N.d.S.C., P.C.L., H.L.G. and R.A.R.; resources, M.R.S., S.A.R., P.C.L., N.d.S.C., R.A.R. and H.L.G.; writing-original draft preparation, M.R.S., S.A.R., 
P.C.L., N.d.S.C., R.A.R. and H.L.G.; writing-review and editing, M.R.S., S.A.R., P.C.L. and N.d.S.C.; visualization, M.R.S., S.A.R., P.C.L., N.d.S.C., R.A.R. and H.L.G.; supervision, P.C.L. and N.d.S.C.; project administration, M.R.S., S.A.R., P.C.L., N.d.S.C., R.A.R. and H.L.G. All authors have read and agreed to the published version of the manuscript.

Funding: This research received no external funding.

Institutional Review Board Statement: Not applicable.

Informed Consent Statement: Not applicable.

Data Availability Statement: Part of the data presented in this study is available at the link: https: / / repositorio.ufscar.br/handle/ufscar/11891?show=full. Other data can be obtained by requesting the author for correspondence.

Acknowledgments: The authors are very thankful to the Capes/Print program and PROPG/UNESP.

Conflicts of Interest: The authors declare no conflict of interest.

\section{References}

1. Yoon, Y.W.; Heo, S.B.; Kim, K.S. Geotechnical performance of waste tires for soil reinforcement from chamber tests. Geotext. Geomembr. 2008, 26, 100-107. [CrossRef]

2. Luwalaga, J.G. Analysing the Behaviour of Soil Reinforced with Polyethylene. Ph.D. Thesis, Stellenbosch University, Stellenbosch, South Africa, 2016; p. 138.

3. Soltani, A.; Deng, A.; Taheri, A.; Mirzababaei, M.; Nikraz, H. Interfacial shear strength of rubber-reinforced clays: A dimensional analysis perspective. Geosynth. Int. 2019, 26, 164-183. [CrossRef]

4. Marçal, R.; Lodi, P.C.; de Souza Correia, N.; Giacheti, H.L.; Rodrigues, R.A.; McCartney, J.S. Reinforcing Effect of Polypropylene Waste Strips on Compacted Lateritic Soils. Sustainability 2020, 12, 9572. [CrossRef]

5. Silveira, M.R.; Lodi, P.C.; de Souza Correia, N.; Rodrigues, R.A.; Giacheti, H.L. Effect of recycled polyethylene terephthalate strips on the mechanical properties of cement-treated lateritic sandy soil. Sustainability 2020, 12, 9801. [CrossRef]

6. Tang, C.; Shi, B.; Gao, W.; Chen, F.; Cai, Y. Strength and mechanical behavior of short polypropylene fiber reinforced and cement stabilized clayey soil. Geotext. Geomembr. 2007, 25, 194-202. [CrossRef]

7. Shukla, S.K.; Sivakugan, N.; Das, B.M. Fundamental concepts of soil reinforcement-An overview. Int. J. Geotech. Eng. 2009, 3, 329-342. [CrossRef]

8. Shukla, S.K. Fundamentals of Fibre-Reinforced Soil Engineering; Springer Nature: Singapore, 2017; ISBN 978-981-10-3061-1.

9. Ehrlich, M.; Almeida, S.; Curcio, D. Hydro-mechanical behavior of a lateritic fiber-soil composite as a waste containment liner. Geotext. Geomembr. 2019, 47, 42-47. [CrossRef]

10. Consoli, N.C.; Montardo, J.P.; Marques Prietto, P.D.; Pasa, G.S. Engineering behavior of a sand reinforced with plastic waste. J. Geotech. Geoenviron. Eng. 2002, 128, 462-472. [CrossRef]

11. Heineck, K.S.; Coop, M.R.; Consoli, N.C. Effect of Microreinforcement of Soils from Very Small to Large Shear Strains. J. Geotech. Geoenviron. Eng. 2005, 131, 1024-1033. [CrossRef]

12. Sotomayor, J.M.G.; Casagrande, M.D.T. The performance of a sand reinforced with coconut fibers through plate load tests on a true scale physical model. Soils Rocks 2018, 41, 361-368. [CrossRef]

13. dos Santos Lopes Louzada, N.; Malko, J.A.C.; Casagrande, M.D.T. Behavior of Clayey Soil Reinforced with Polyethylene Terephthalate. J. Mater. Civ. Eng. 2019, 31, 04019218. [CrossRef]

14. Eldesouky, H.M.; Morsy, M.M.; Mansour, M.F. Fiber-reinforced sand strength and dilation characteristics. Ain Shams Eng. J. 2016, 7, 517-526. [CrossRef]

15. Anagnostopoulos, C.A.; Tzetzis, D.; Berketis, K. Shear strength behaviour of polypropylene fibre reinforced cohesive soils. Geomech. Geoengin. 2014, 9, 241-251. [CrossRef]

16. Mirzababaei, M.; Arulrajah, A.; Horpibulsuk, S.; Aldava, M. Shear strength of a fibre-reinforced clay at large shear displacement when subjected to different stress histories. Geotext. Geomembr. 2017, 45, 422-429. [CrossRef]

17. Mirzababaei, M.; Mohamed, M.; Arulrajah, A.; Horpibulsuk, S.; Anggraini, V. Practical approach to predict the shear strength of fibre-reinforced clay. Geosynth. Int. 2018, 25, 50-66. [CrossRef]

18. Murray, J.J.; Frost, J.D.; Wang, Y. Behavior of a sandy silt reinforced with discontinuous recycled fiber inclusions. Transp. Res. Rec. 2000, 1714, 9-17. [CrossRef]

19. Özkul, Z.H.; Baykal, G. Shear behavior of compacted rubber fiber-clay composite in drained and undrained loading. J. Geotech. Geoenviron. Eng. 2007, 133, 767-781. [CrossRef]

20. Suffri, N.; Jeludin, M.; Rahim, S. Behaviour of the Undrained Shear Strength of Soft Clay Reinforced with Natural Fibre. In IOP Conference Series: Materials Science and Engineering; IOP Publishing: Seoul, Korea, 2019; Volume 690, p. 012005. [CrossRef]

21. Botero, E.; Ossa, A.; Sherwell, G.; Ovando-Shelley, E. Stress-strain behavior of a silty soil reinforced with polyethylene terephthalate (PET). Geotext. Geomembr. 2015, 43, 363-369. [CrossRef] 
22. Fathi, H.; Jamshidi Chenari, R.; Vafaeian, M. Shaking Table Study on PET Strips-Sand Mixtures Using Laminar Box Modelling. Geotech. Geol. Eng. 2019, 38, 683-694. [CrossRef]

23. Festugato, L.; Menger, E.; Benezra, F.; Kipper, E.A.; Consoli, N.C. Fibre-reinforced cemented soils compressive and tensile strength assessment as a function of filament length. Geotext. Geomembr. 2017, 45, 77-82. [CrossRef]

24. Onyelowe, K.C.; Bui Van, D.; Ubachukwu, O.; Ezugwu, C.; Salahudeen, B.; Nguyen Van, M.; Ikeagwuani, C.; Amhadi, T.; Sosa, F.; $\mathrm{Wu}, \mathrm{W}$; et al. Recycling and reuse of solid wastes; a hub for ecofriendly, ecoefficient and sustainable soil, concrete, wastewater and pavement reengineering. Int. J. Low-Carbon Technol. 2019, 14, 440-451. [CrossRef]

25. Peddaiah, S.; Burman, A.; Sreedeep, S. Experimental Study on Effect of Waste Plastic Bottle Strips in Soil Improvement. Geotech. Geol. Eng. 2018, 36, 2907-2920. [CrossRef]

26. Santoni, B.R.L.; Tingle, J.S.; Members, A.; Webster, S.L. Engineering properties of sand-fiber mixtures for road construction. J. Geotech. Geoenviron. Eng. 2001, 127, 258-268. [CrossRef]

27. Dos Santos, A.P.S.; Consoli, N.C.; Baudet, B.A. The mechanics of fibre-reinforced sand. Geotechnique 2010, 60, 791-799. [CrossRef]

28. Sivakumar Babu, G.L.; Chouksey, S.K. Stress-strain response of plastic waste mixed soil. Waste Manag. 2011, 31, 481-488. [CrossRef] [PubMed]

29. Zhao, J.J.; Lee, M.L.; Lim, S.K.; Tanaka, Y. Unconfined compressive strength of PET waste-mixed residual soils. Geomech. Eng. 2015, 8, 53-66. [CrossRef]

30. Anagnostopoulos, C.A.; Papaliangas, T.T.; Konstantinidis, D.; Patronis, C. Shear Strength of Sands Reinforced with Polypropylene Fibers. Geotech. Geol. Eng. 2013, 31, 401-423. [CrossRef]

31. Freilich, B.J.; Li, C.; Zornberg, J.G. Effective shear strength of fiber-reinforced clays. In Proceedings of the 9th International Conference on Geosynthetics-Geosynthetics: Advanced Solutions for a Challenging World, ICG 2010, Guarujá, Brazil, 23 May 2010; pp. 1997-2000.

32. Li, C.; Zornberg, J.G. Shear Strength Behavior of Soils Reinforced with Weak Fibers. J. Geotech. Geoenviron. Eng. 2019, 145, 2-8. [CrossRef]

33. Muir Wood, D.; Diambra, A.; Ibraim, E. Fibres and soils: A route towards modelling of root-soil systems. Soils Found. 2016, 56, 765-778. [CrossRef]

34. Kong, Y.; Zhou, A.; Shen, F.; Yao, Y. Stress-dilatancy relationship for fiber-reinforced sand and its modeling. Acta Geotech. 2019, 14, 1871-1881. [CrossRef]

35. Kong, Y. Stress-Dilatancy Relationship for Fiber-Reinforced Soil. In Proceedings of the China-Europe Conference on Geotechnical Engineering, Vienna, Austria, 13-16 August 2018.

36. Rowe, P.W. The stress-dilatancy relation for static equilibrium of an assembly of particles in contact. Proc. R. Soc. London. Ser. A Math. Phys. Sci. 1962, 269, 500-527. [CrossRef]

37. Dołżyk-Szypcio, K. Direct Shear Test for Coarse Granular Soil. Int. J. Civ. Eng. 2019, 17, 1871-1878. [CrossRef]

38. Szypcio, Z. Stress-Dilatancy for Soils. Part IV: Experimental Validation for Simple Shear Conditions. Stud. Geotech. Mech. 2017, 39, 81-88. [CrossRef]

39. Yousefpour, V.; Hamidi, A.; Ghanbari, A. Shear Strength-Dilation Characteristics of Silty and Clayey Sands. J. Eng. Geol. 2020, 13, 177-205.

40. Townsend, F.C. Geotechnical Characteristics of Residual Soils. J. Geotech. Eng. 1985, 111, 77-94. [CrossRef]

41. Giacheti, H.L.; Bezerra, R.C.; Rocha, B.P.; Rodrigues, R.A. Seasonal influence on cone penetration test: An unsaturated soil site example. J. Rock Mech. Geotech. Eng. 2019, 11, 361-368. [CrossRef]

42. ASTM D2487-17 Standard Practice for Classification of Soils for Engineering Purposes (Unified Soil Classification System); ASTM International: West Conshohocken, PA, USA, 2017; pp. 1-10.

43. ASTM D4452-14 Standard Practice for X-ray Radiography of Soil Samples 2014; ASTM International: West Conshohocken, PA, USA, 2014; pp. 1-14.

44. ASTM D7928-17 Standard Test Method for Particle-Size Distribution (Gradation) of Fine-Grained Soils Using the Sedimentation (Hydrometer) Analysis; ASTM International: West Conshohocken, PA, USA, 2017; pp. 1-25.

45. ASTM D854-14 Standard Test Methods for Specific Gravity of Soil Solids by Water Pycnometer; ASTM International: West Conshohocken, PA, USA, 2014; pp. 1-7.

46. ASTM D698: Standard Test Methods for Laboratory Compaction Characteristics of Soil Using Standard Effort (12 $400 \mathrm{ft}$-lbf/ft3 (600 $k N-m / m 3))$; ASTM International: West Conshohocken, PA, USA, 2012; Volume 3, pp. 1-13.

47. ASTM D4318-17e1 Standard Test Methods for Liquid Limit, Plastic Limit, and Plasticity Index of Soils; ASTM International: West Conshohocken, PA, USA, 2017; Volume 4, pp. 1-14.

48. Diambra, A.; Ibraim, E. Modelling of fibre-cohesive soil mixtures. Acta Geotech. 2014, 9, 1029-1043. [CrossRef]

49. Li, C.; Zornberg, J.G. Interface shear strength in fiber-reinforced soil. In Proceedings of the 16th International Conference on Soil Mechanics and Geotechnical Engineering, Osaka, Japan, 12-16 September 2005; Volume 3, pp. 1373-1376. [CrossRef]

50. Rowland Otoko, G. Stress-Strain Behaviour of an Oil Palm Fibre Reinforced Lateritic Soil. Int. J. Eng. Trends Technol. 2014, 14, 295-298. [CrossRef]

51. Darvishi, A.; Erken, A. Effect of Polypropylene Fiber on Shear Strength Parameters of Sand. In Proceedings of the 3rd World Congress on Civil, Structural, and Environmental Engineering (CSEE'18), Budapest, Hungary, 8-10 April 2018 ; p. 13. 
52. Falorca, I.; Pinto, M.I.M. Effect of short, randomly distributed polypropylene microfibres on shear strength behaviour of soils. Geosynth. Int. 2011, 18, 2-11. [CrossRef]

53. ASTM D3080/D3080M-11. Standard Test Method for Direct Shear Test of Soils under Consolidated Drained Conditions; ASTM International: West Conshohocken, PA, USA, 2011; Volume 4, pp. 1-9. [CrossRef]

54. Gelder, C.; Fowmes, G.J. Mixing and compaction of fibre- and lime-modified cohesive soil. Proc. Inst. Civ. Eng. Ground Improv. 2016, 169, 98-108. [CrossRef]

55. Kumar, P.; Singh, S.P. Fiber-reinforced fly ash subbases in rural roads. J. Transp. Eng. 2008, 134, 171-180. [CrossRef]

56. Mirzababaei, M.; Miraftab, M.; Mohamed, M.; McMahon, P. Unconfined compression strength of reinforced clays with carpet waste fibers. J. Geotech. Geoenviron. Eng. 2013, 139, 483-493. [CrossRef]

57. Khatri, V.N.; Dutta, R.K.; Venkataraman, G.; Shrivastava, R. Shear strength behaviour of clay reinforced with treated coir fibres. Period. Polytech. Civ. Eng. 2016, 60, 135-143. [CrossRef]

58. Sadek, S.; Najjar, S.S.; Freiha, F. Shear strength of fiber-reinforced sands. J. Geotech. Geoenviron. Eng. 2010, 136, 490-499. [CrossRef]

59. Ibraim, E.; Diambra, A.; Muir Wood, D.; Russell, A.R. Static liquefaction of fibre reinforced sand under monotonic loading. Geotext. Geomembr. 2010, 28, 374-385. [CrossRef]

60. Mohamad, H.; Maher, M.H.; Gray, D.H. Static response of sands reinforced with randomly distributed fibers. J. Geotech. Eng. 1990, 116, 1661-1677.

61. Consoli, N.C.; Thomé, A.; Girardello, V.; Ruver, C.A. Uplift behavior of plates embedded in fiber-reinforced cement stabilized backfill. Geotext. Geomembr. 2012, 35, 107-111. [CrossRef]

62. Bera, A.K.; Chandra, S.N.; Ghosh, A.; Ghosh, A. Unconfined compressive strength of fly ash reinforced with jute geotextiles. Geotext. Geomembr. 2009, 27, 391-398. [CrossRef]

63. Futai, M.M.; Almeida, M.S.S.; Lacerda, W.A. Yield, Strength, and Critical State Behavior of a Tropical Saturated Soil. J. Geotech. Geoenviron. Eng. 2004, 130, 1169-1179. [CrossRef]

64. Yetimoglu, T.; Salbas, O. A study on shear strength of sands reinforced with randomly distributed discrete fibers. Geotext. Geomembr. 2003, 21, 103-110. [CrossRef]

65. Shao, W.; Cetin, B.; Li, Y.; Li, J.; Li, L. Experimental Investigation of Mechanical Properties of Sands Reinforced with Discrete Randomly Distributed Fiber. Geotech. Geol. Eng. 2014. [CrossRef]

66. BS 8002:1994. Code of Practice for Earth Retaining Structures; British Standards Institution: London, UK, 1994; pp. 1-114. 